\title{
Estimasi Imbuhan Airtanah DAS Cidanau Menggunakan Model Neraca Kesetimbangan Air
}

\author{
Gumilar Utamas Nugraha ${ }^{\text {* }}$, Priyo Hartanto ${ }^{1}$, Hendra Bakti ${ }^{1}$, Asep \\ Mulyono 1
}

${ }^{1}$ Pusat Penelitian Geoteknologi, Lembaga Ilmu Pengetahuan Indonesia (LIPI)

\begin{abstract}
ABSTRAK Airtanah merupakan faktor penting bagi pembangunan ekonomi di wilayah Serang Barat dan Kota Cilegon, dimana kedua wilayah ini terletak di dalam DAS Cidanau. Selain itu, imbuhan airtanah sangat dibutuhkan untuk memastikan keberlanjutan dan pengelolaan airtanah di suatu wilayah. Penelitian ini bertujuan untuk mengestimasi resapan airtanah DAS Cidanau menggunakan metode Thornthwaite, Dingman, Dingman-Hamon dan Edijatno-Michel. Keempat metode estimasi pengimbuhan airtanah tersebut merupakan metode kesetimbangan air yang berlandaskan model neraca kesetimbangan air. Software ESPERE version 2 digunakan untuk menganalisis kesetimbangan air berdasarkan keempat metode tersebut. Hasil penelitian menunjukkan terdapat tiga klaster nilai imbuhan airtanah di lokasi penelitian yaitu Thronthwaite (157 $\mathrm{mm} /$ tahun), Dingman-Hamon (125 $\mathrm{mm} /$ tahun $)$ dan Edijatno-Michel (186 mm/tahun). Ketiga perbedaan nilai ini disebabkan oleh adanya perbedaan kalkulasi nilai hujan efektif metodemetode tersebut, dimana metode Dingman dan metode Edijatno-Michel memiliki kecenderungan pola kalkulasi yang sama. Imbuhan airtanah hanya sekitar 7,8 - 11,6 \% dari jumlah hujan tahunan yang ada di lokasi penelitian. Sekitar $80 \%$ dari hujan tahunan di konversikan menjadi evapotranspirasi potensial dan sisanya menjadi limpasan permukaan.
\end{abstract}

Naskah masuk : 31 Agustus 2020

Naskah direvisi : 24 Desember 2020

Naskah diterima : 28 Desember 2020

*Penulis korespondensi.

Email: g.utamas.n@gmail.com
Dengan mempertimbangkan kondisi geologi hidrometeorologi Indonesia yang cenderung kompleks, metode Thornthwaite dan metode Dingman-Hamon direkomendasikan untuk perhitungan nilai imbuhan airtanah yang ada di Indonesia.

Kata kunci: airtanah, imbuhan, kesetimbangan air

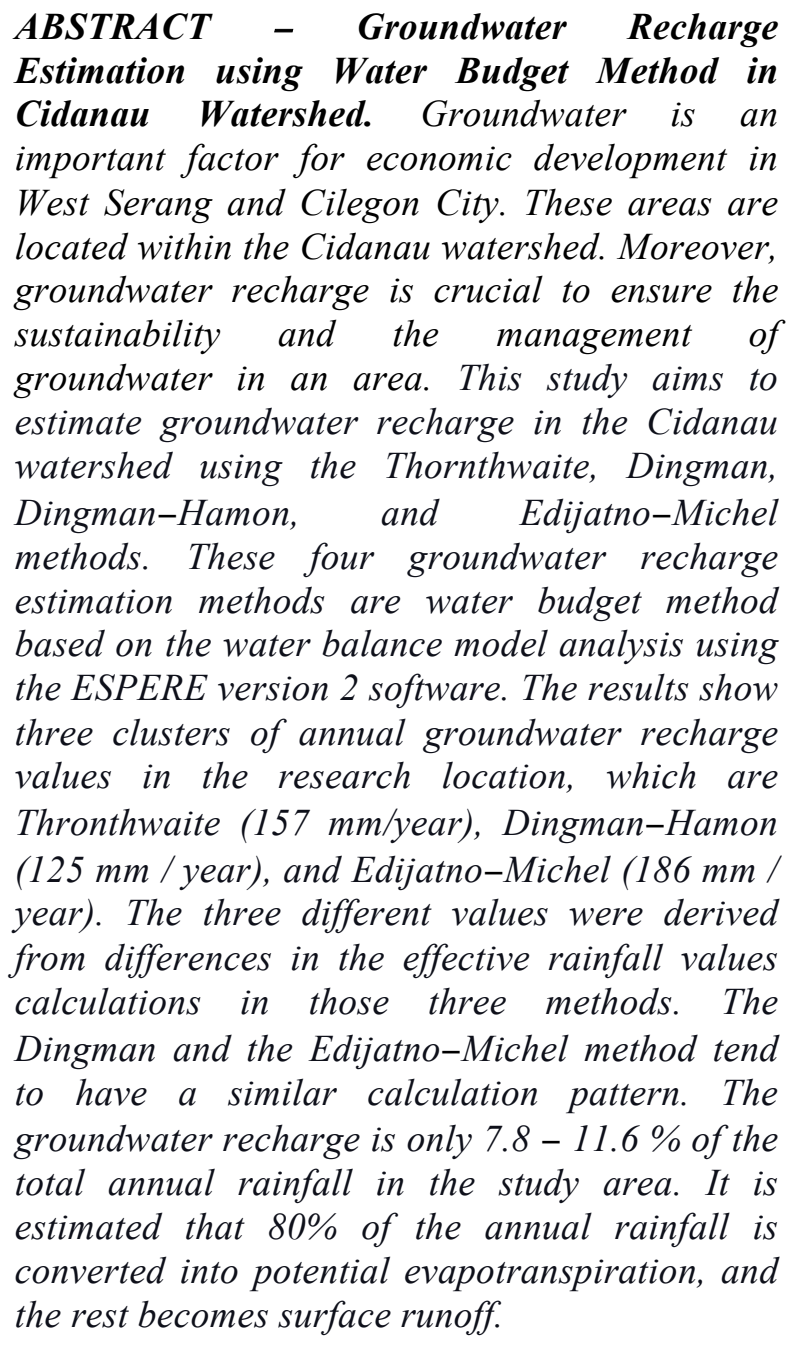

Keywords: groundwater, recharge, water budget 


\section{PENDAHULUAN}

Kebutuhan air semakin meningkat dikarenakan meningkatnya pertumbuhan penduduk, ekonomi, dan perubahan iklim global yang berpengaruh terhadap ketersediaan air (Vörösmarty et al., 2000; Rogers dan Hall, 2003). Airtanah memainkan peran penting dalam menahan dampak perubahan iklim terhadap sumber daya air. Saat ini kondisi airtanah telah dieksploitasi secara berlebihan di seluruh dunia (Anderson et al., 2002; Konikow dan Kendy, 2005; Gleeson et al., 2012; Basu dan Van Meter, 2014). Airtanah sangat bergantung pada imbuhan, dimana air hujan memegang peranan penting dalam imbuhan airtanah (Böhlke, 2002; de Vries dan Simmers, 2002; Sanford, 2002; Mauser dan Ludwig, 2016). Infiltrasi air hujan meresap kedalam zona vadose menuju zona jenuh air (aquifer) (Yeh et al., 2007; Seiler dan Gat, 2007). Proses imbuhan airtanah merupakan faktor penting dari banyak proses hidrologi, yang menjadikannya variabel penting dalam siklus air (Sanford, 2002).

Daerah Aliran Sungai (DAS) Cidanau terletak di Kabupaten Serang Provinsi Banten. Selain ditempati oleh salah satu rawa pegunungan, Cagar Alam Rawa Danau juga menjadi sumber air untuk wilayah sekitarnya (Hartanto, 2017). DAS Cidanau memiliki peranan vital dalam penyediaan kebutuhan air di Kota/Kabupaten Serang dan Kota Cilegon (Hartanto, 2017). Dengan luas 22.322 hektare, DAS Cidanau dapat memasok air dengan debit rata-rata 2.000 liter per detik (Hartanto, 2017). Lebih dari 100 perusahaan memiliki ketergantungan dengan air yang bersumber dari DAS Cidanau (Hartanto, 2017).

Seiring meningkatnya pertumbuhan ekonomi dan penduduk di Kawasan Cilegon dan Serang Barat, kebutuhan air baku di wilayah ini menjadi semakin meningkat. Kebutuhan air baku untuk daerah tersebut tidak hanya di supply oleh air sungai tetapi juga di support oleh airtanah (Hartanto, 2017; Hartanto et al., 2019). Karena airtanah sangat bergantung pada proses pengimbuhan untuk keberlanjutannya, maka informasi mengenai kuantitas imbuhan airtanah di daerah ini sangatlah penting. Selain itu perkiraan imbuhan airtanah yang akurat sangat penting untuk pengelolaan airtanah yang efisien dan berkelanjutan, karena sumber daya air sangat penting bagi pembangunan ekonomi di wilayah ini, mengingat wilayah Serang Barat dan Kota Cilegon telah ditetapkan sebagai kawasan industri (Hartanto, 2017).

Penelitian ini bertujuan untuk mengestimasi resapan airtanah DAS Cidanau menggunakan metode Thornthwaite, Dingman, Dingman-Hamon, dan Edijatno-Michel. Keempat metode estimasi pengimbuhan airtanah tersebut merupakan metode kesetimbangan air yang berlandaskan model neraca kesetimbangan air. Model neraca air banyak digunakan dalam penelitian berbasis DAS (Zhang et al., 1999; Boughton, 2005; Barron et al., 2013; Wagner et al., 2013). Peneliti menggunakan berbagai pendekatan untuk memperkirakan imbuhan (Simmers, 1987; Tilahun dan Merkel, 2009; Islam et al., 2016; Niazi et al., 2017). Berbagai metode langsung dan tidak langsung serta model numerik telah digunakan untuk mengestimasi imbuhan airtanah (Sanford, 2002; Singh et al., 2019). Banyak peneliti menggunakan metode Thornthwaite (Mintz dan Serafini, 1992; Xu dan Chen, 2005; Westenbroek et al., 2010; Hartanto, 2017), Dingman (D'Almeida et al., 2006), Dingman-Hamon (Křeček et al., 2006; Kobiyama, 2008; Bakundukize et al., 2011), dan Edijatno-Michel (Wahyuningsih et al., 2010; Hidayah et al., 2011) untuk menganalisis kesetimbangan air. Kemudian beberapa peneliti memanfaatkan metode kesetimbangan air untuk mengestimasi nilai imbuhan airtanah menggunakan Thornthwaite, Dingman-Hamon dan Edijatno-Michel (Xu dan Chen, 2005; Westenbroek et al., 2010; Guardiola-Albert et al., 2015).

\section{LOKASI DAN GEOLOGI DAERAH PENELITIAN}

Menurut Hartanto et al. (2019), Daerah Aliran Sungai (DAS) Cidanau menempati wilayah yang terletak di Kecamatan Padarincang, Kecamatan Cinangka, Kecamatan Mancak, Kecamatan Pabuaran, Kecamatan Ciomas, Kabupaten Serang dan Kecamatan Cadasari Kabupaten Pandeglang. Secara geografi daerah penelitian terletak pada koordinat antara $06^{\circ} 07^{\prime} 10^{\prime \prime}-06^{\circ} 19^{\prime} 10^{\prime \prime} \mathrm{LS}$ dan $105^{\circ} 51^{\prime} 30^{\prime \prime}$ - $106^{\circ} 03^{\prime} 00^{\prime \prime}$ BT (Gambar 1). Dasar DAS Cidanau terletak pada ketinggian 91 meter di atas permukaan laut (dpl). Daerah tangkapan (catchment area) batas DAS pada ketinggian 794 meter dpl (Gunung 


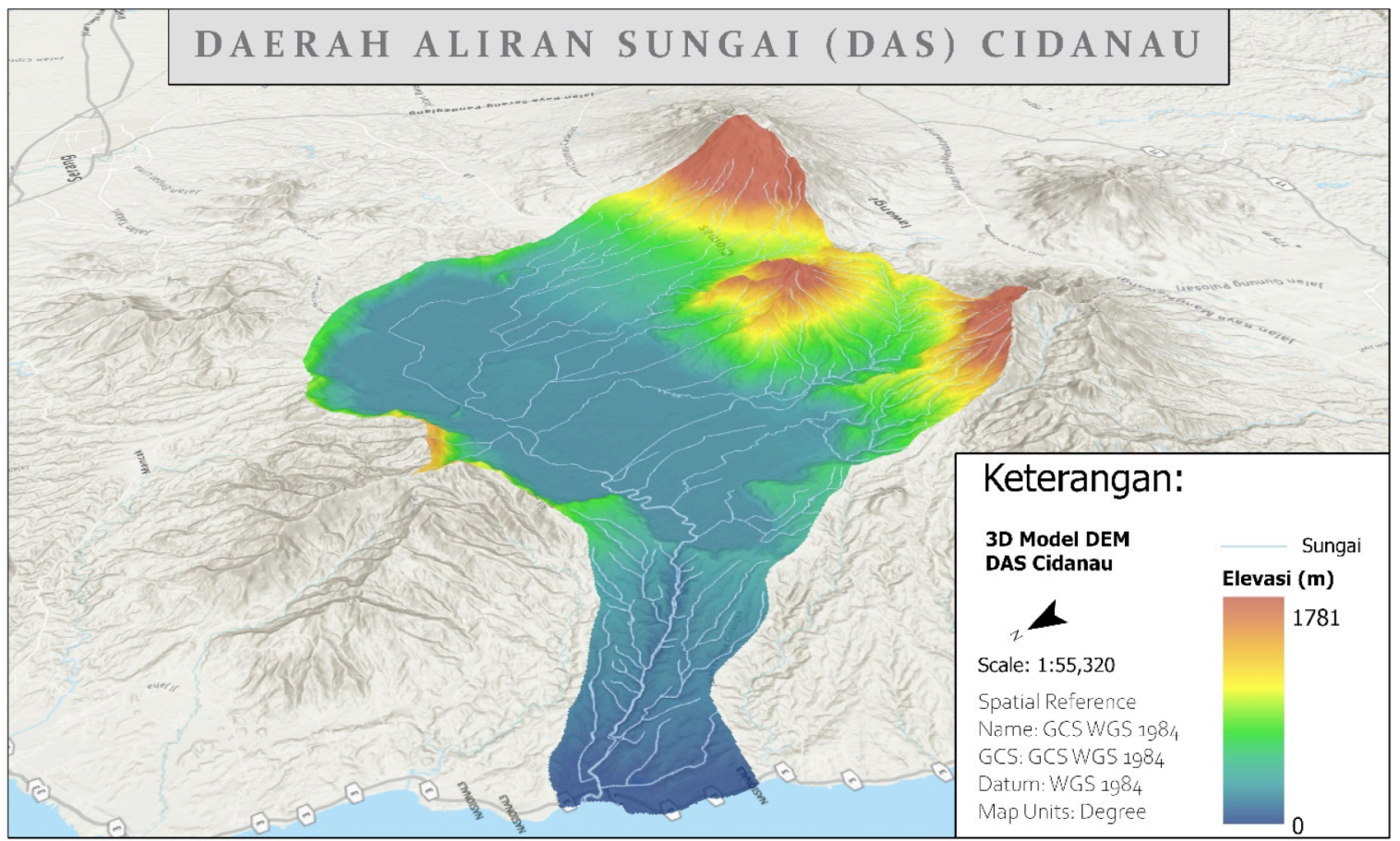

Gambar 1. Peta lokasi penelitian daerah aliran sungai (DAS) Cidanau.

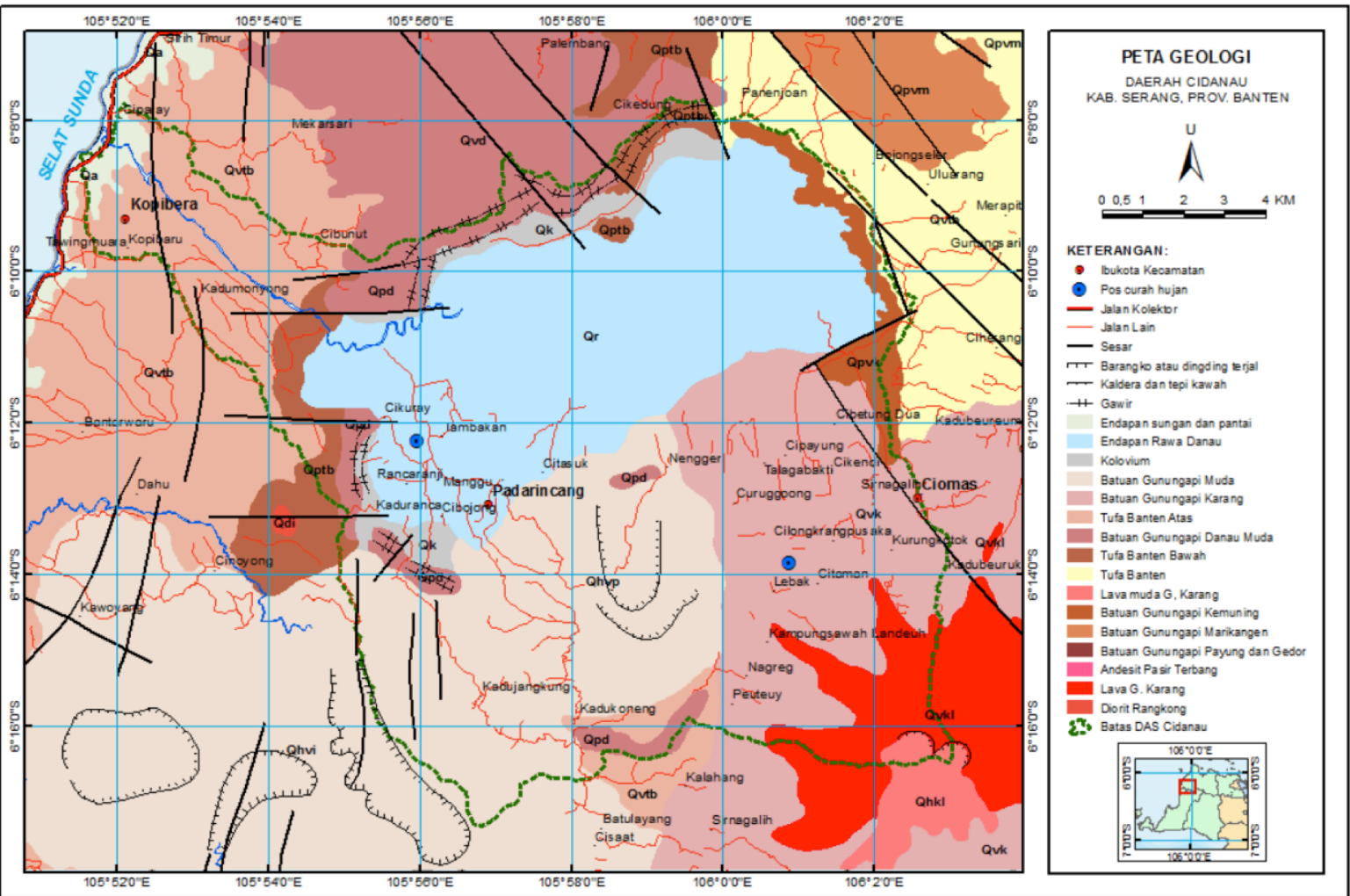

Gambar 2. Peta geologi DAS Cidanau (Santosa, 1991; Rusmana et al., 1991 dalam Hartanto et al., 2007). 


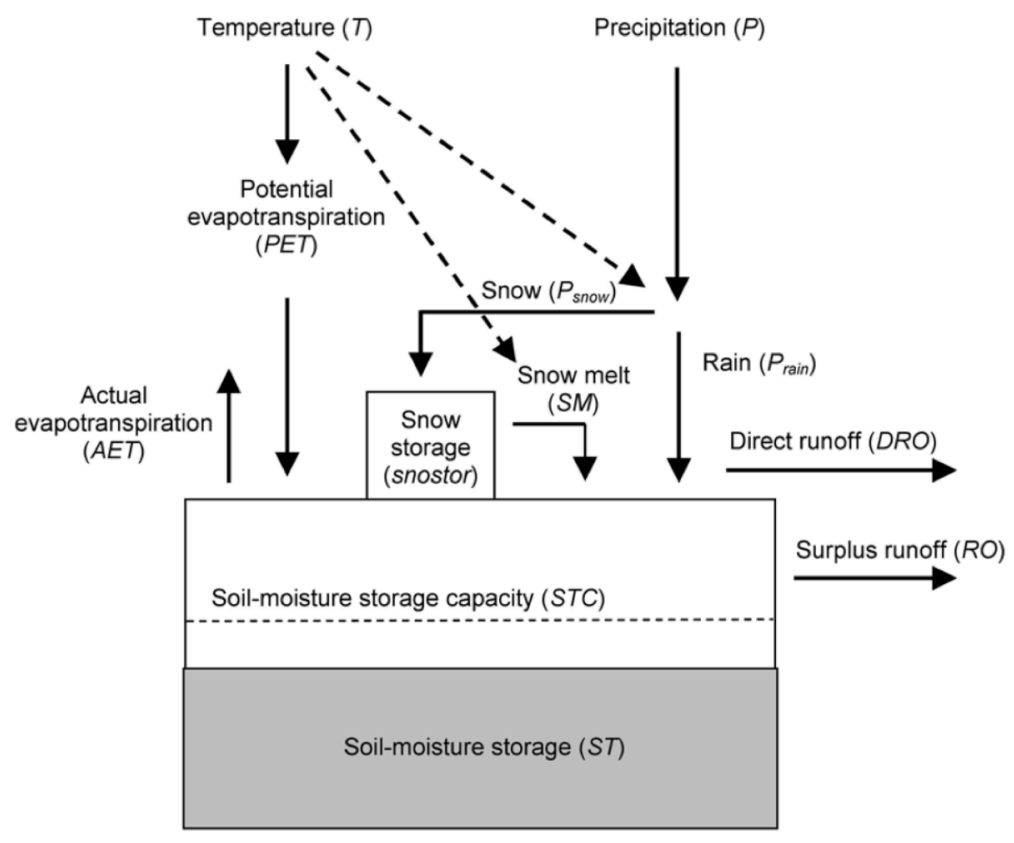

Gambar 3. Model kesetimbangan air Thornwaite (Westenbroek et al., 2008).

Condong) dan 778 meter dpl (Gunung Karang) di sisi selatan, 741 meter dpl (Gunung Gede) di sisi utara, dan 361 meter dpl (Gunung Kupak) di sisi timur DAS (Hartanto, 2017). Secara geografis, DAS Cidanau terletak di Kabupaten Serang bagian barat yang berbatasan endapan batuan gunungapi muda (Qhv) tersusun atas breksi gunungapi, lava, tuf, aliran lahar dan hasil letusan gunungapi lainnya (Gunung Aseupan, Gunung Parakasak). Endapan Tuf Banten Atas (Qvtb) terdiri atas tuf, tuf batuapung dan tuf pasiran (di bagian atas) dan tuf hablur, tuf lapili berbatuapung, tuf kaca dan sisipan tuf lempungan di bagian bawah. Endapan batuan gunungapi danau muda (Qvd) tersusun atas lava aliran bersusun andesit atau basal terkekarkan, breksi gunungapi dan tuf. Tuf Banten Bawah (Qptb) yang tersusun atas breksi, algomerat, tuf berbatuapung, tuf lapili dan tuf pasiran. Batuan Gunungapi Danau Tua (Qpd) berupa lava aliran bersusun andesit atau basal terkekarkan, breksi gunungapi dan tuf (Gambar 2). Dinding utara dari Rawa Danau memperlihatkan gawir yang relatif terjal dan lurus, itu menunjukkan bahwa dinding Rawa Danau ini dikontrol stuktur sesar. Sepanjang dan sekeliling dinding Rawa Danau
(Van Der Kaars et al., 2001) banyak dijumpai mataair, paling banyak didinding sisi utara dan sisi selatan, bahkan beberapa telah dimanfaatkan oleh penduduk setempat.

\section{METODE}

Penelitian ini menggunakan software ESPERE version 2 (Lanini et al., 2016). ESPERE adalah aplikasi MS Excel yang memungkinkan penerapan beberapa metode yang umum digunakan untuk memperkirakan imbuhan airtanah secara cepat dan bersamaan (Lanini et al., 2016). Menurut data yang tersedia, pengguna dapat menerapkan dan membandingkan hasil dari tiga metode empiris (Guttman et al., 1995; Turc, 1954; Kessler, 1967), tiga metode kesetimbangan air (Thornthwaite, 1948; Dingman, 2002; Edijatno \& Michel, 1989), metode fluktuasi muka airtanah (Delin et al., 2007) dan tiga algoritma pemisahan hidrograf (Chapman dan Maxwell, 1996; Eckhardt, 2005; Lanini, 2015). Pada penelitian ini akan digunakan metode kesetimbangan air (Thornthwaite, 1948; Dingman, 2002; dan Edijatno \& Michel, 1989) pada software ESPERE version 2 


\section{Thornthwaite}

Persamaan neraca air yang dibuat oleh Thornthwaite dan Mather pada tahun 1957 (persamaan 1) disusun berdasarkan model kesetimbangan air pada Gambar 3. Neraca air dapat dihitung pada luasan dan periode waktu tertentu menurut keperluannya (Mc Gabe dan Markstorm, 2007).

$P=E T_{0}+\Delta S_{t}$

dimana $P$ adalah presipitasi ( $\mathrm{mm} / \mathrm{bulan}), E T_{0}$ adalah evapotranspirasi (mm/bulan), $\Delta S_{t}$ merupakan perubahan cadangan air ( $\mathrm{mm} / \mathrm{bulan})$.

Nilai recharge airtanah dapat diestimasi menggunakan persamaan:

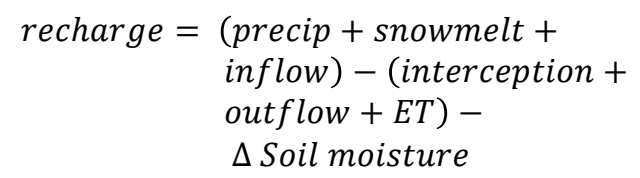

recharge $=$ Sources \pm Sinks

\section{Dingman-Hamon}

Model kesetimbangan air Dingman-Hamon diilustrasikan seperti pada Gambar 4 dan memiliki persamaan sebagai berikut (Dingman, 2015):

$P+G_{\text {in }}-\left(Q+E T+G_{\text {out }}\right)=\Delta S$

dimana $P$ merupakan presipitasi $\left(L t^{-1}\right), G_{\text {in }}$ adalah airtanah yang masuk pada suatu daerah aliran sungai $\left(L t^{-1}\right), \quad Q$ adalah limpasan permukaan $\left(L t^{-1}\right), E T$ adalah evapotranspirasi $\left(L t^{-1}\right), G_{\text {out }}$ adalah airtanah yang keluar pada suatu daerah aliran sungai $\left(L t^{-1}\right), \Delta S$ merupakan perubahan simpanan air $\left(L t^{-1}\right)$.

$Q=P-E T-\Delta S$

Dimana $Q$ adalah limpasan permukaan $\left(L t^{-1}\right), P$ adalah presipitasi $\left(L t^{-1}\right), E T$ adalah evapotranspirasi $\left(L t^{-1}\right)$, dan $\Delta S$ merupakan perubahan simpanan air $\left(L t^{-1}\right)$.

Persamaan Hamon untuk estimasi nilai evapotranspirasi potensial adalah (Hamon, 1961):

$P E T_{\text {Hamon }}=13.97 \times d \times D^{2} \times W_{t}$

Dimana $P E T_{\text {Hamon }}$ adalah evapotranspirasi potensial $(\mathrm{mm}), d$ adalah jumlah hari dalam satu bulan, $D$ adalah rata-rata jumlah penyinaran matahari dalam 12 jam, $W_{t}$ adalah uap air jenuh dalam $\mathrm{gr} / \mathrm{m}^{3}$ dihitung menggunakan persamaan:

$W_{t}=\frac{4.95 \times e^{0.062 \times T}}{100}$

dimana $T$ merupakan temperatur bulanan ratarata (Hamon, 1961).

Persamaan di atas dapat disederhanakan menjadi:

$P=Q+E+T+R$

dimana $P$ adalah presipitasi, $E$ merupakan evaporasi, $T$ adalah transpirasi, dan $R$ adalah

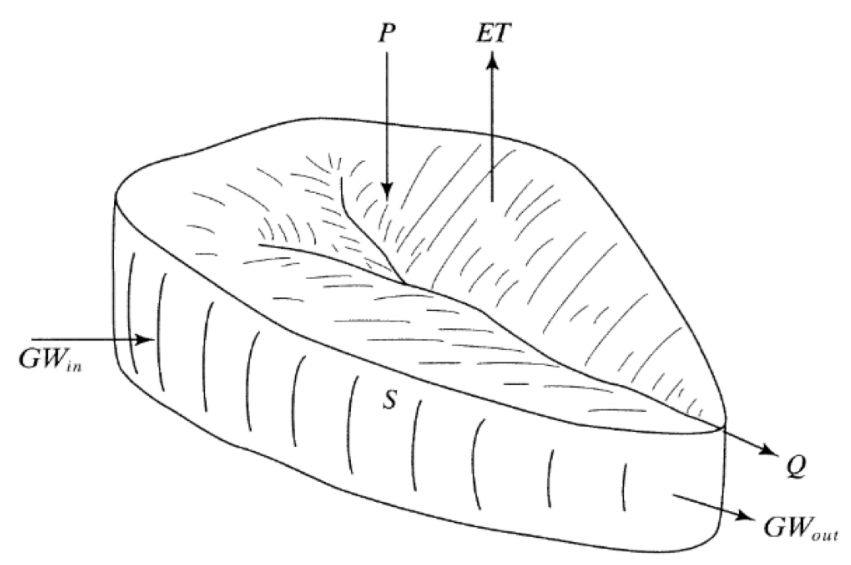

Gambar 4. Kesetimbangan air metode Dingman-Hamon (Dingman, 2015) 


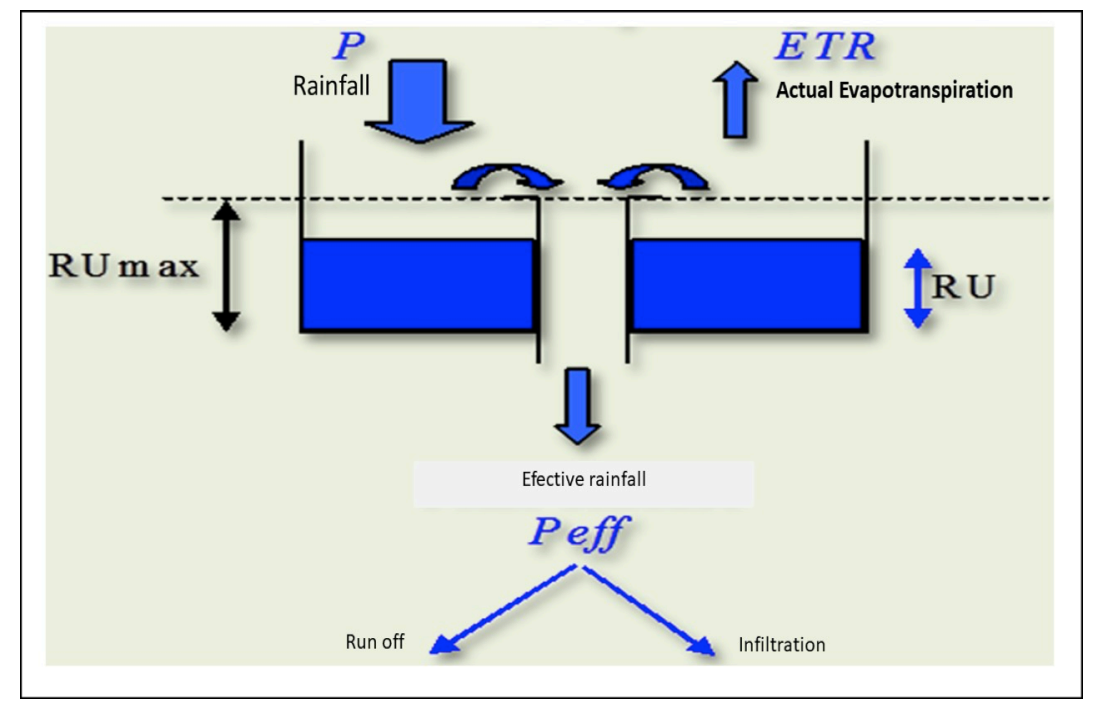

Gambar 5. Model kesetimbangan air Edijatno-Michel (Lanini, 2015).

imbuhan airtanah.

Maka nilai imbuhan/recharge airtanah dapat diperoleh melalui persamaan:

$R=P-Q$

dimana $R$ adalah imbuhan $\left(L t^{-1}\right), P$ merupakan presipitasi $\left(L t^{-1}\right)$, dan $Q$ adalah limpasan permukaan $\left(L t^{-1}\right)$.

\section{Edijatno-Michel}

Pemodelan air hujan-limpasan permukaan yang diukur berdasarkan parameter-parameter bebas dari data curah hujan harian, pertama kali dikenalkan oleh Edijatno dan Mitchel (1989) (Gambar 5). Imbuhan airtanah merupakan besaran yang diambil sebagai sisa dari air hujan yang ter evapotranspirasi serta yang mengalir menjadi air limpasan. Pendekatan Edijatno-Michel didasarkan atas dua kondisi,

Tabel 1. Algoritma Edijatno-Michel.

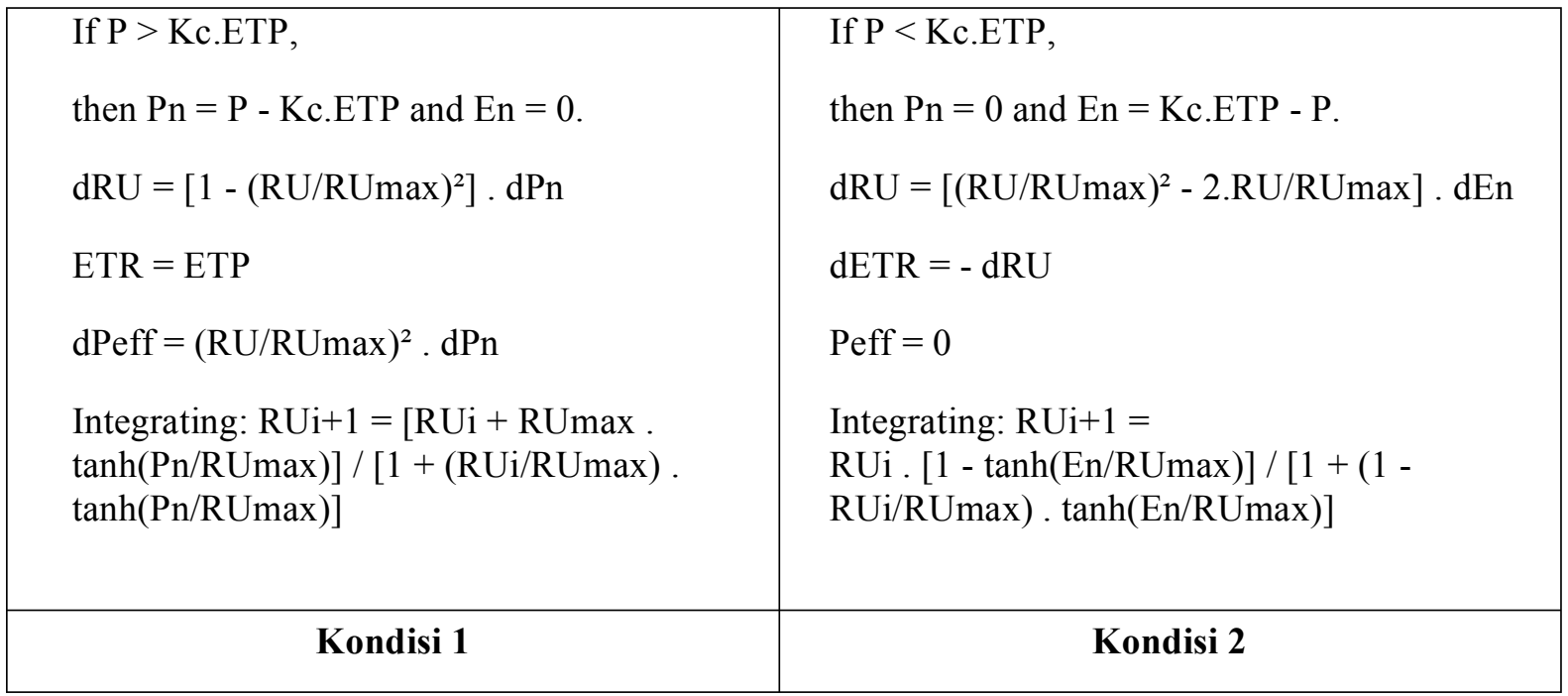


yaitu kondisi pertama dimana nilai curah hujan lebih besar dibandingkan dengan nilai evapotranspirasi potensial dikalikan dengan koefisien tanaman, serta kondisi kedua dimana nilai curah hujan lebih kecil dibandingkan dengan nilai evapotranspirasi dikalikan dengan nilai koefisien tanamannya. Detail algoritma dapat dilihat pada Tabel 1, dimana $\mathrm{P}$ adalah curah hujan, Kc adalah Koefisien tanaman, ETP adalah evpotranspirasi potensial, RU adalah cadangan air dalam tanah, Pn adalah hujan efektif, En adalah bagian dari evapotranspirasi potensial yang tidak berasal dari hujan, ETR merupakan evapotranspirasi aktual.

Tabel 2. Pengaturan parameter software ESPERE version 2.

\begin{tabular}{|c|c|c|}
\hline Property & Unit & Value \\
\hline $\begin{array}{l}\text { Groundwater recharge area } \\
\text { surface }\end{array}$ & $\mathrm{km}^{2}$ & 226 \\
\hline $\begin{array}{l}\text { Infiltration/Effective } \\
\text { rainfall ratio (ERI) }\end{array}$ & I & $0,27^{*}$ \\
\hline Soil-water storage capacity & $\mathrm{mm}$ & $125 * *$ \\
\hline Latitude & $\circ$ & $-6,5$ \\
\hline Specific Yield (Sy) & / & $8.0000 * * *$ \\
\hline $\begin{array}{l}\text { Hydrogeological catchment } \\
\text { surface }\end{array}$ & $\mathrm{km}^{2}$ & 226 \\
\hline $\begin{array}{l}\text { Keterangan: } \\
{ }^{*} \text { Jaworska-Szulc (2009) } \\
{ }^{* *} \text { Agriculture (2015) } \\
\text { *** Johnson (1967) }\end{array}$ & & \\
\hline
\end{tabular}

\section{Ketersediaan data}

Data yang digunakan merupakan data yang bersumber dari Stasiun BMKG Kelas 1 Serang dengan koordinat $X=106,11000 \mathrm{E}, \mathrm{Y}=6,11185 \mathrm{~S}$, $\mathrm{Z}=100$ meter. Data dapat diperoleh pada $\mathrm{http}: / /$ dataonline.bmkg.go.id/home dengan rincian data harian berupa curah hujan, temperatur minimum, temperatur maksimum, temperatur rata-rata, lama penyinaran matahari, kelembaban rata-rata, kecepatan angin maksimum, arah angin, kecepatan angin rata-rata, dan evapotranspirasi potensial (Gambar 6). Dari Gambar 6 diketahui bahwa arah angin terbanyak pada tanggal 1 Januari 2015 hingga 31 Desember 2019. Adapun data yang dibutuhkan untuk proses analisis resapan airtanah menggunakan software ESPERE adalah data hujan harian, evapotranspirasi potensial, dan data temperatur. Software ESPERE memerlukan beberapa pengaturan parameter seperti yang disajikan dalam Tabel 2.

Nilai evapotranspirasi potensial dihitung menggunakan software CROPWAT 8 (FAO, 2018). Software CROPWAT 8 menghitung nilai evapotranspirasi potensial menggunakan persamaan (Monteith, 1965):

$E T_{0}=\frac{0.408 \Delta\left(R_{n}-G\right)+\gamma \frac{900}{T+273} U_{2}\left(e_{s}-e_{a}\right)}{\Delta+\gamma\left(1+0.34 U_{2}\right)}$

Dimana $E T_{0}$ adalah evapotranspirasi potensial $\left(m m\right.$ day $\left.^{-1}\right), \Delta$ adalah kurva kemiringan uap $\left(k P a 1^{0} C^{-1}, R_{n}\right.$ adalah radiasi $\left(M J m^{-2} d a y^{-1}\right)$, $G$ adalah fluks panas tanah $\left(M J m^{-2} d a y^{-1}\right), T$ adalah temperatur udara $\left(1^{0} C\right), U_{2}$ adalah kecepatan angin $\left(m s^{-1}\right), e_{s}$ adalah uap jenuh $(k P a), e_{a}$ adalah tekanan uap actual $(k P a), \gamma$ adalah konstanta pscycrhometrik $\left(k P a 1^{0} C^{-1}\right)$.

Ada pun input yang dibutuhkan software CROPWAT 8 untuk menghitung nilai evapotranspirasi potensial adalah temperatur minimal dan temperatur maksimal, kelembaban udara, kecepatan angin dan lama penyinaran matahari.

\section{HASIL}

\section{Curah hujan dan hujan efektif}

Terdapat 1826 data curah hujan harian dari tanggal 1 Januari 2015 hingga 31 Desember 2019 (Gambar 7). Data ini memiliki rentang $89 \mathrm{~mm}$. Angka tersebut diperoleh dari angka curah hujan maksimum dikurangi curah hujan minimum. Curah hujan maksimum dilokasi penelitian adalah 89,6 mm, sedangkan curah hujan minimum dilokasi penelitian memiliki nilai 0 $\mathrm{mm}$. Jika curah hujan dijumlahkan selama 1826 hari maka diperoleh nilai $8011 \mathrm{~mm}$ dan jika nilai ini dirata-ratakan selama 1826 hari diperoleh nilai $4,3 \mathrm{~mm}$. 

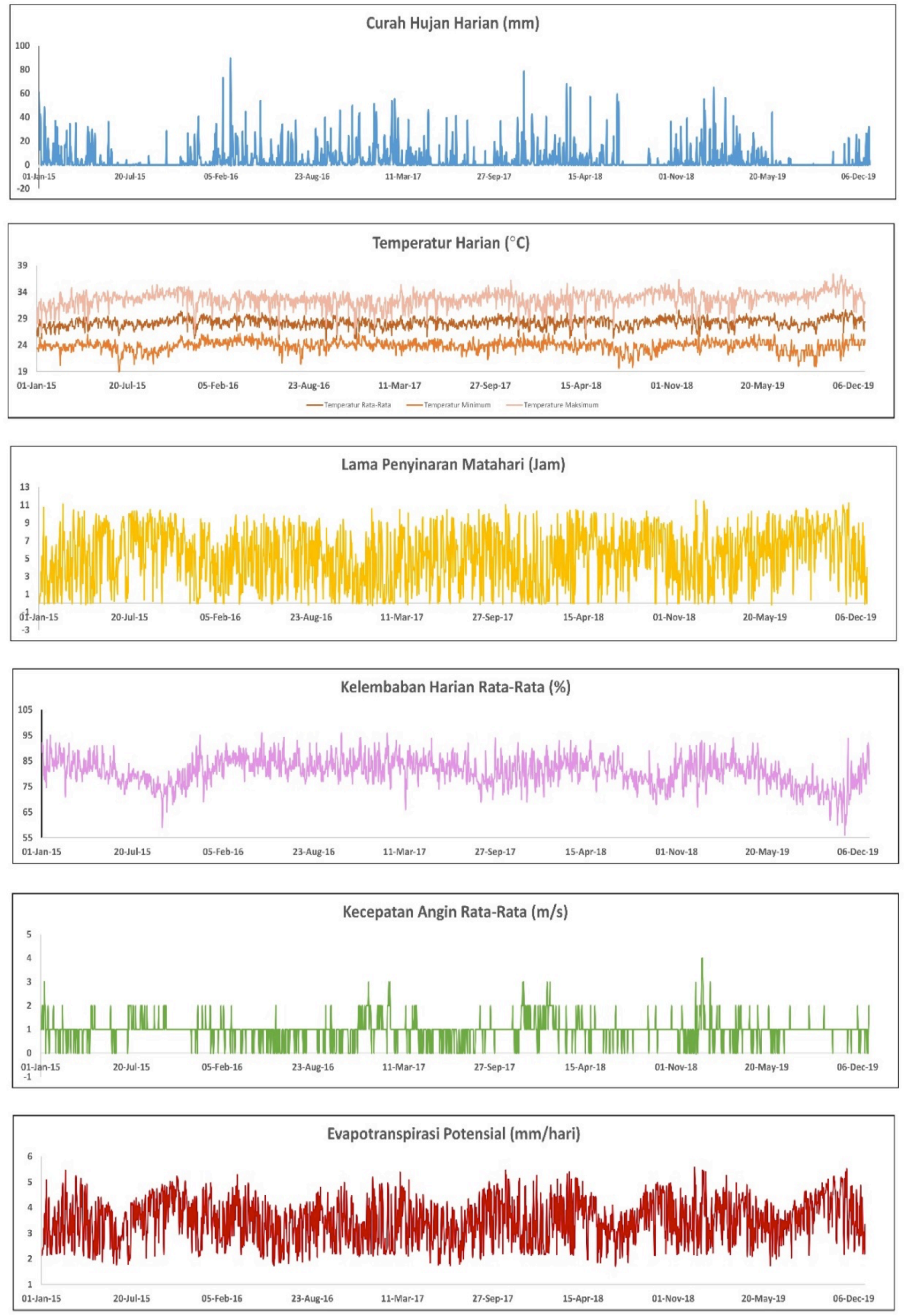

Gambar 6. Data curah hujan, temperatur, lama penyinaran matahari, kelembaban, kecepatan angin dan evapotranspirasi potensial hasil perhitungan menggunakan software CROPWAT 8. 


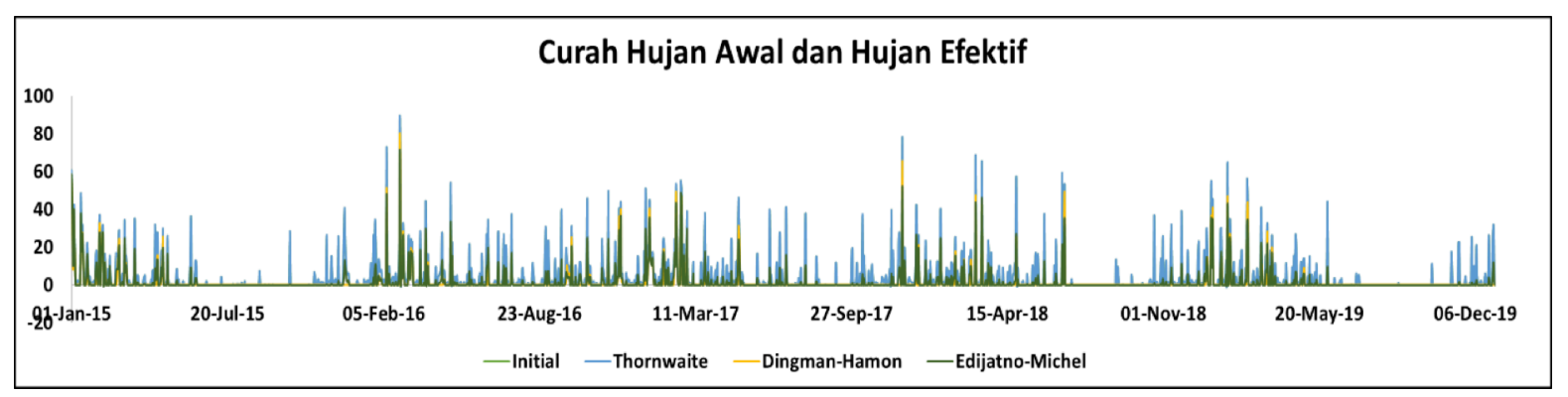

Gambar 7. Data curah hujan dan hujan efektif.

Hujan efektif merupakan hasil antara nilai $P(\mathrm{~mm})-$ ETo $(\mathrm{mm})$. Hujan efektif harian masing-masing metode (Thornthwaite, Dingman, Dingman-Hamon dan Edijatno-Michel) disajikan pada Gambar 7. Hujan efektif metode Thornthwaite memiliki rentang statistik 86,02 $\mathrm{mm}$. Berdasarkan metode ini nilai minimum yang diperoleh adalah $0 \mathrm{~mm}$, sedangkan nilai maksimum yang bisa diperoleh adalah $86,02 \mathrm{~mm}$. Jika dijumlahkan selama 1826 hari maka diperoleh nilai 2913,85 mm. Metode ini memiliki nilai hujan efektif rata-rata sebesar $1,59 \mathrm{~mm}$.

Hujan efektif berdasarkan metode Dingman memiliki rentang statistik $86,02 \mathrm{~mm}$. Metode ini memiliki nilai hujan efektif minimum sejumlah 0 $\mathrm{mm}$ dan hujan efektif maksimum sejumlah 86,02 mm. Jika dijumlahkan selama 1826 hari, maka hujan efektif berdasarkan metode Dingman memiliki nilai $3337,03 \mathrm{~mm}$. Hujan efektif ratarata selama 1826 hari berdasarkan metode Dingman adalah $1,82 \mathrm{~mm}$.

Berdasarkan metode Dingman-Hamon, rentang statistik yang diperoleh berdasarkan data hujan efektif selama 1826 hari adalah $80,27 \mathrm{~mm}$. Nilai hujan efektif minimum berdasarkan metode Dingman-Hamon adalah $0 \mathrm{~mm}$, sedangkan nilai hujan efektif maksimum berdasarkan mettode ini adalah $80,27 \mathrm{~mm}$. Jika dijumlahkan selama 1826 hari, jumlah hujan efektif berdasarkan metode Dingman-Hamon adalah $2311 \mathrm{~mm}$. Nilai ratarata sebesar $1,26 \mathrm{~mm}$ diperoleh hasil rata-rata hujan efektif selama 1826 hari menggunakan metode Dingman-Hamon.

Statistik deskriptif hujan efektif berdasarkan

Tabel 3. Rata-rata curah hujan efektif bulanan (2015-2019).

\begin{tabular}{lcccc}
\hline Bulan & Thornthwaite & Dingman & Dingman-Hamon & Edijatno-Michel \\
\hline Januari & 154,2 & 164,8 & 129,0 & 161,8 \\
Februari & 153,4 & 157,7 & 126,7 & 154,9 \\
Maret & 99,1 & 104,3 & 81,0 & 110,1 \\
April & 31,0 & 41,6 & 21,7 & 45,6 \\
Mei & 30,0 & 30,4 & 20,9 & 36,1 \\
Juni & 24,2 & 33,2 & 14,8 & 34,1 \\
Juli & 9,6 & 14,6 & 2,4 & 16,8 \\
Agustus & 0,0 & 0,0 & 0,0 & 3,6 \\
September & 8,6 & 14,0 & 5,9 & 11,4 \\
Oktober & 17,0 & 17,4 & 11,4 & 19,7 \\
November & 8,6 & 16,2 & 3,1 & 23,6 \\
Desember & 46,8 & 73,2 & 45,2 & 72,0 \\
\hline
\end{tabular}




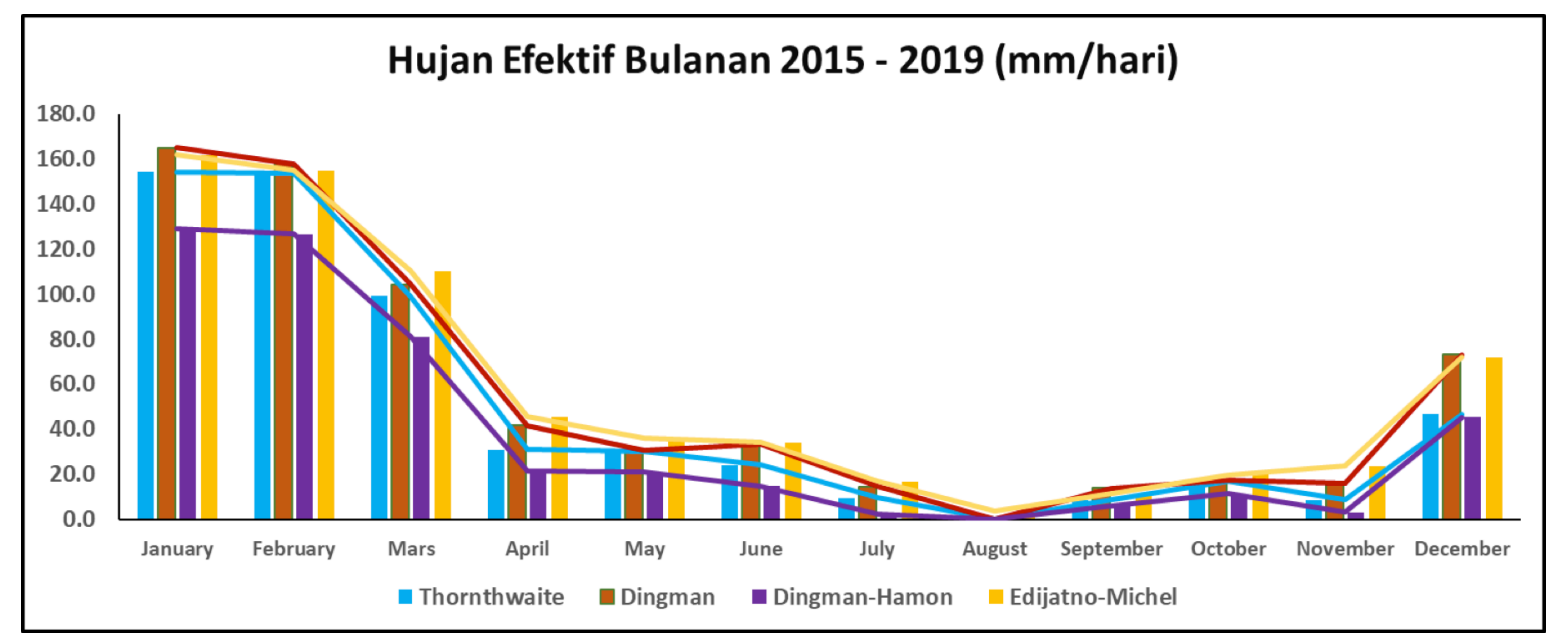

Gambar 8. Hujan efektif bulanan metode Thornthwaite, Dingman, Dingman-Hamon, dan Edijatno-Michel.

metode Edijatno-Michel menunjukkan bahwa rentang statistik yang diperoleh adalah 71,66 mm. Nilai hujan efektif maksimum berdasarkan metode Edijatno-Michel adalah 71,66 $\mathrm{mm}$ dan hujan efektif minimum sebesar $0 \mathrm{~mm}$. Jumlah hujan efektif selama 1826 hari sebesar 3448,95 $\mathrm{mm}$, sedangkan rata-rata hujan efektif selama 1826 hari sebesar $1,88 \mathrm{~mm}$.

Rata-rata curah hujan efektif bulanan dari Januari 2015 hingga Desember 2019 disajikan pada Tabel 3 dan Gambar 8. Secara keseluruhan keempat metode menunjukkan pola hujan efektif bulanan yang sama, dimana nilai hujan efektif tertinggi berada di bulan Januari dan terendah berada di bulan Agustus. Pada metode Thornthwaite dengan jumlah data (N) 12 (Januari hingga Desember), memiliki nilai tertinggi sebesar $154,20 \mathrm{~mm}$ dan nilai terendah sebesar 0 $\mathrm{mm}$. Rentang nilai statistik pada metode ini sebesar $154,20 \mathrm{~mm}$. Jika dijumlahkan maka total hujan efektifnya adalah $582,5 \mathrm{~mm}$ dengan nilai rata-rata $48,5 \mathrm{~mm}$.
Metode hujan efektif Dingman memiliki rentang statistik $164,80 \mathrm{~mm}$. Pada metode ini nilai maksimum yang diperoleh adalah 164,80 mm sedangkan nilai minimum yang diperoleh adalah $0 \mathrm{~mm}$, dengan jumlah data $(\mathrm{N})$ statistik sebanyak 12, nilai total yang diperoleh selama 12 bulan adalah $667,40 \mathrm{~mm}$. Nilai rata-rata yang diperoleh metode Dingman adalah 55,6 mm.

Metode Dingman-Hamon memiliki nilai maksimum sebesar $129 \mathrm{~mm}$ dan nilai minimum sebesar $0 \mathrm{~mm}$. Rentang statistik pada metode Dingman-Hamon adalah $129 \mathrm{~mm}$. Nilai total yang diperoleh pada metode ini sebesar $462 \mathrm{~mm}$, dengan nilai rata-rata sebesar $38,5 \mathrm{~mm}$ pada jumlah data $(\mathrm{N})$ statistik sebanyak 12 buah.

Pada metode Edijatno-Michel dengan jumlah data sebanyak 12 buah memiliki nilai rata-rata sebesar $57,4 \mathrm{~mm}$. Metode ini memiliki nilai maksimum sebesar $161,8 \mathrm{~mm}$ dan nilai minimum sebesar 3,60 mm. Rentang statistik pada metode ini sebesar 158,2 $\mathrm{mm}$ dengan jumlah total hujan

Tabel 4. Curah hujan efektif tahunan.

\begin{tabular}{lllll}
\hline Tahun & Thornthwaite & Dingman & Dingman-Hamon & Edijatno-Michel \\
\hline 2015 & 640,3 & 689,8 & 531,7 & 734,6 \\
2016 & 781,8 & 888,9 & 572,5 & 878,0 \\
2017 & 703,4 & 828,6 & 572,8 & 855,5 \\
2018 & 388,7 & 486,3 & 284,8 & 498,3 \\
2019 & 399,7 & 443,5 & 349,8 & 482,7 \\
\hline
\end{tabular}




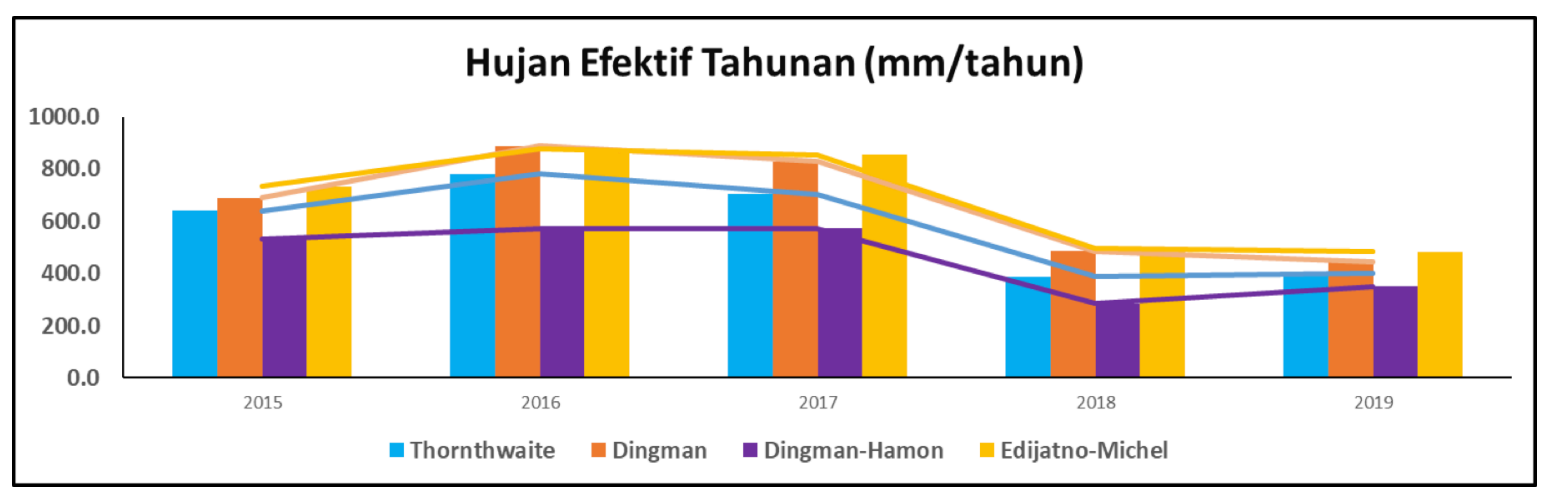

Gambar 9. Hujan efektif tahunan metode Thornthwaite, Dingman, Dingman-Hamon, dan Edijatno-Michel.

efektif untuk 12 bulan sebesar $689,7 \mathrm{~mm}$.

Curah hujan efektif tahunan pada Tabel 4 dan Gambar 9 menunjukkan bahwa tahun 2016 merupakan tahun dengan hujan efektif tahunan tertinggi dibandingkan dengan empat tahun lainnya untuk semua metode (Thornthwaite, Dingman, Dingman-Hamon dan Edijatno-Michel). Tahun 2018 dan 2019 memiliki nilai hujan efektif tahunan yang terendah dibandingkan dengan tahun lainnya untuk semua metode (Thornthwaite, Dingman, Dingman-Hamon dan Edijatno-Michel). Grafik menunjukkan hujan efektif tahunan meningkat dari tahun 2015, mencapai puncak di tahun 2016 dan 2017, kemudian cenderung melandai di tahun 2018 dan 2019, kecuali untuk metode Dingman-Hamon dimana pada metode ini grafik cenderung landai di tahun 2015-2017 dan 2018-2019.

Metode Thornthwaite memiliki nilai hujan efektif tahunan tertinggi pada tahun 2016 sebesar 781,8 $\mathrm{mm} /$ tahun dan terendah pada tahun 2018 sebesar $388,7 \mathrm{~mm} / \mathrm{tahun}$. Hujan efektif metode Thornthwaite kembali naik pada tahun 2019 sebesar 399,7 mm/tahun. Tahun 2015 hujan efektif metode Thornthwaite memiliki nilai sebesar $640,3 \mathrm{~mm} /$ tahun. Hujan efektif tahunan menggunakan metode Thornthwaite turun secara signifikan pada tahun 2018 (388,7 mm/tahun) dibandingkan tahun sebelumnya (703,4 $\mathrm{mm} /$ tahun). Metode Dingman memiliki nilai hujan efektif tahunan yang lebih tinggi dibandingkan dengan metode Thornthwaite. Meskipun demikian kedua metode ini tetap memperlihatkan pola yang sama.
Hujan efektif tahunan tertinggi berdasarkan metode Dingman berada pada tahun $2016(888,9$ $\mathrm{mm} / \mathrm{tahun}$ ) dan terendah berada pada tahun 2019 (443,5 mm/tahun). Seperti pada metode Thornthwaite, penurunan signifikan hujan efektif tahunan terjadi pada tahun $2018 \quad(486,3$ $\mathrm{mm} /$ tahun) jika dibandingkan dengan tahun sebelumnya $(828,6 \mathrm{~mm} / \mathrm{tahun})$. Nilai hujan efektif tahunan terus menurun hingga tahun 2019 (443,5 mm/tahun).

Estimasi hujan efektif tahunan berdasarkan metode Dingman-Hamon cenderung rendah dibandingkan dua metode sebelumnya (Thornthwaite dan Dingman). Metode ini memiliki pola grafik yang cenderung berbeda dibandingkan dua metode sebelumnya. Metode ini memiliki hujan efektif tahunan tertinggi pada tahun 2017 (572,8 mm/tahun) dan terendah tahun 2018 (284,8 mm/tahun). Hujan efektif tahunan terendah berdasarkan Metode Dingman-Hamon merupakan yang terendah dibandingkan dengan tiga metode lainnya. Nilai hujan efektif Metode Dingman-Hamon cenderung landai pada tahun 2016 (572,5 mm/tahun) hingga 2017 (572,8 $\mathrm{mm} /$ tahun). Nilai ini kemudian turun signifikan pada tahun $2018(284,8 \mathrm{~mm} /$ tahun $)$. Nilai ini kemudian naik kembali di tahun 2019 (349,8 $\mathrm{mm} /$ tahun).

Estimasi hujan efektif tahunan berdasarkan Metode Edijatno-Michel memiliki nilai estimasi tertinggi diantara ketiga metode lainnya. Hujan efektif tahunan tertinggi berada pada tahun 2016 sebesar $878 \mathrm{~mm} /$ tahun dan terendah tahun 2019 sebesar $482,7 \mathrm{~mm} /$ tahun. Seperti tiga metode lainnya penurunan hujan efektif tahunan terjadi secara signifikan pada tahun 2018 sebesar 498,3 
Tabel 5. Tabel perbandingan nilai imbuhan airtanah rata-rata bulanan (2015-2019).

\begin{tabular}{lllll}
\hline Bulan & $\begin{array}{l}\text { Thornthwaite } \\
(\mathrm{mm} / \mathrm{bulan})\end{array}$ & $\begin{array}{l}\text { Dingman } \\
(\mathrm{mm} / \mathrm{bulan})\end{array}$ & $\begin{array}{l}\text { Dingman-Hamon } \\
(\mathrm{mm} / \mathrm{bulan})\end{array}$ & $\begin{array}{l}\text { Edijatno-Michel } \\
\text { (mm/bulan) }\end{array}$ \\
\hline Januari & 41,64 & 44,51 & 34,83 & 43,69 \\
Februari & 41,42 & 42,58 & 34,21 & 41,84 \\
Maret & 26,76 & 28,16 & 21,88 & 29,74 \\
April & 8,38 & 11,23 & 5,87 & 12,31 \\
Mei & 8,11 & 8,21 & 5,64 & 9,74 \\
Juni & 6,54 & 8,96 & 4,01 & 9,20 \\
Juli & 2,60 & 3,94 & 0,65 & 4,54 \\
Agustus & 0,00 & 0,00 & 0,00 & 0,96 \\
September & 2,33 & 3,78 & 1,60 & 3,09 \\
Oktober & 4,59 & 4,71 & 3,09 & 5,32 \\
November & 2,33 & 4,37 & 0,84 & 6,38 \\
Desember & 12,64 & 19,75 & 12,21 & 19,44 \\
\hline
\end{tabular}

mm/tahun. Nilai hujan efektif tahunan berdasarkan metode Edijatno-Michel terus menurun sejak $2016(878,0 \mathrm{~mm} /$ tahun $)$ hingga 2019 (482,7 mm/tahun).

\section{Imbuhan airtanah}

\section{Imbuhan bulanan}

Secara umum imbuhan airtanah tertinggi terjadi di bulan Januari dan terendah berada di bulan Agustus (Tabel 5 dan Gambar 10). Keempat metode (Thornthwaite, Dingman, Dingman-Hamon dan Edijatno-Michel) memiliki pola imbuhan airtanah rata-rata bulanan yang sama. Grafik terus menurun di bulan
Februari hingga Agustus, kemudian grafik terus naik hingga bulan Desember.

Berdasarkan metode Thornthwaite, nilai imbuhan airtanah rata-rata bulanan tertinggi berada di bulan Januari dengan 41,64 $\mathrm{mm} / \mathrm{bulan}$ dan terendah berada di bulan Agustus dengan 0 $\mathrm{mm} /$ bulan. Jumlah total imbuhan airtanah ratarata bulanan dengan jumlah data $(\mathrm{N}) 12$ adalah $157,4 \mathrm{~mm} /$ tahun. Bulan September dan November memiliki nilai imbuhan airtanah yang sama sebesar 2,33 $\mathrm{mm} /$ bulan. Terdapat penurunan imbuhan airtanah dari bulan Oktober $(4,59 \mathrm{~mm} / \mathrm{bulan}) \mathrm{ke}$ bulan November $(2,33$ $\mathrm{mm} /$ bulan).

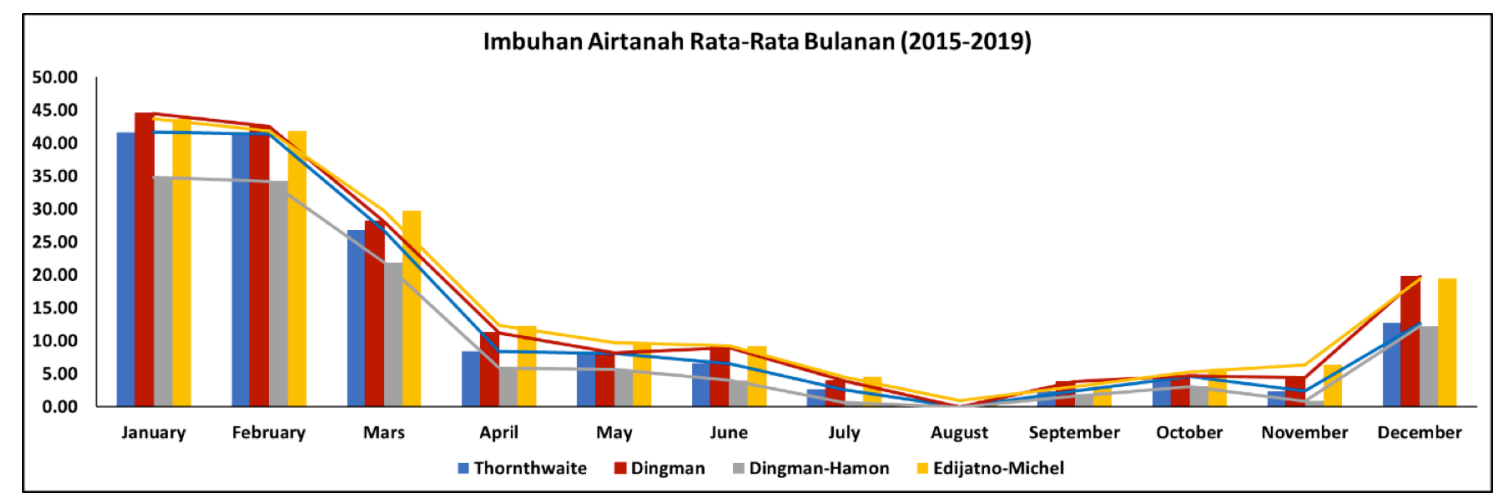

Gambar 10. Imbuhan airtanah rata-rata bulanan (2015-2019). 


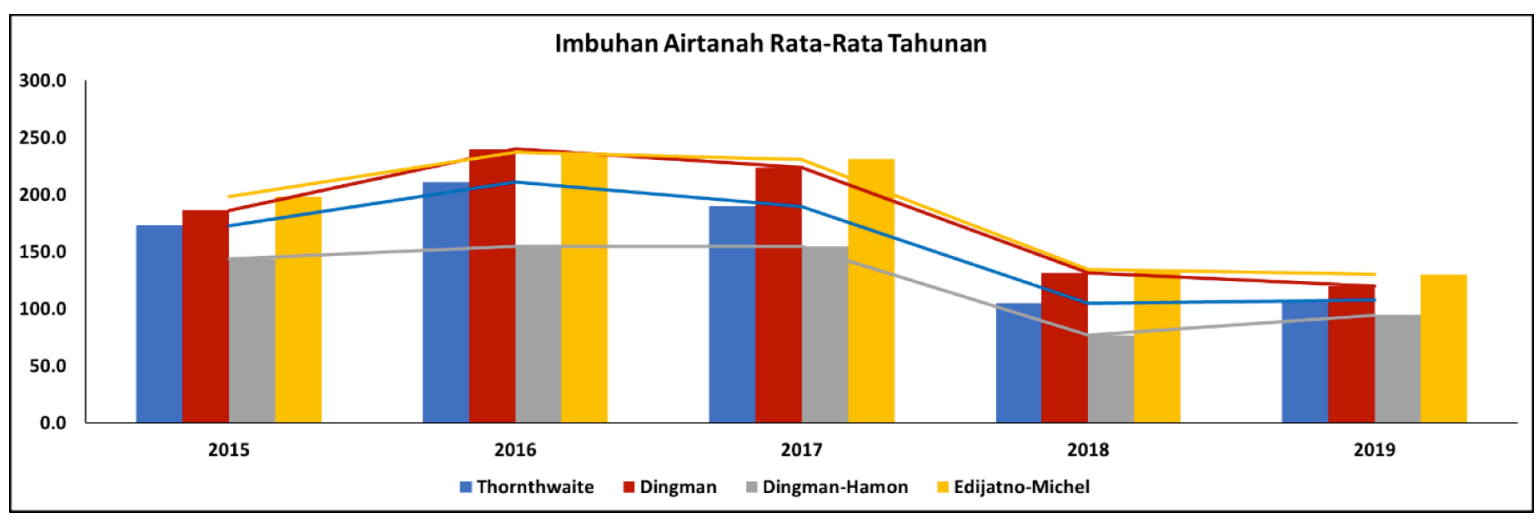

Gambar 11. Imbuhan airtanah rata-rata tahunan.

Berdasarkan metode Dingman, nilai imbuhan airtanah rata-rata bulanan tertinggi berada di bulan Januari dengan 41,64 $\mathrm{mm} /$ bulan dan terendah berada di bulan Agustus dengan 0 $\mathrm{mm} /$ bulan. Hasil ini menunjukkan kesamaan pola dengan metode Thornthwaite, namun estimasi imbuhan airtanah rata-rata bulanan metode Dingman memiliki nilai estimasi yang lebih besar. Grafik yang ditunjukkan oleh metode Dingman cenderung menurun pada periode Januari hingga Agustus dan cenderung naik pada periode September hingga Desember. Jumlah total imbuhan airtanah rata-rata bulanan dengan jumlah data (N) 12 adalah 180,2 mm/tahun.

Nilai imbuhan airtanah rata-rata bulanan berdasarkan metode Dingman-Hamon memiliki nilai estimasi terkecil diantara ketiga metode lainnya (Thornthwaite, Dingman dan Edijatno-Michel). Nilai imbuhan airtanah ratarata bulanan tertinggi berada di bulan Januari $(34,83 \mathrm{~mm} /$ bulan$)$ dan terendah berada di bulan Agustus (0 $\mathrm{mm} /$ bulan $)$. Nilai imbuhan hasil estimasi metode Dingman-Hamon pada bulanbulan tertentu hampir mendekati nilai 0 $\mathrm{mm} /$ bulan (Juli dan November). Jumlah rata-rata bulanan metode Dingman-Hamon jika dikalkulasi secara tahunan menghasilkan nilai $124,83 \mathrm{~mm} /$ tahun).

\section{Imbuhan tahunan}

Imbuhan airtanah rata-rata tahunan menunjukan pola yang hampir sama untuk keempat metode (Gambar 11). Metode Edijatno-Michel memiliki nilai estimasi imbuhan yang tertinggi diantara ketiga metode lainnya. Metode Dingman-Hamon memiliki estimasi nilai imbuhan terendah diantara ketiga metode lainnya. Keempat metode mengkonfirmasi bahwa imbuhan airtanah di tahun 2018 dan 2019 cenderung menurun dibandingkan tiga tahun sebelumnya (20152017).

Pada tabel rata-rata imbuhan airtanah tahunan (Tabel 6), nilai imbuhan airtanah tahunan tertinggi berdasarkan metode Thornthwaite

Tabel 6. Tabel perbandingan rata-rata imbuhan airtanah tahunan.

Tahun Thornthwaite Dingman Dingman-Hamon Edijatno-Michel

\begin{tabular}{lcccc}
\hline 2015 & 172,9 & 186,2 & 143,6 & 198,3 \\
2016 & 211,1 & 240,0 & 154,6 & 237,1 \\
2017 & 189,9 & 223,7 & 154,7 & 231,0 \\
2018 & 104,9 & 131,3 & 76,9 & 134,5 \\
2019 & 107,9 & 119,7 & 94,4 & 130,3 \\
\hline
\end{tabular}


terjadi pada tahun $2016(211,1 \mathrm{~mm} / \mathrm{tahun})$ dan terendah terjadi pada tahun $2018 \quad(104,9$ $\mathrm{mm} / \mathrm{tahun})$. Berdasarkan metode Dingman imbuhan airtanah tertinggi terjadi pada tahun 2016 (240 mm/tahun) dan terendah terjadi pada tahun 2019 (119,7 mm/tahun). Metode Dingman-Hamon memberikan estimasi jumlah imbuhan airtanah tertinggi pada tahun 2017 (154,7 mm/tahun) dan terendah pada tahun 2018 (76,9 $\mathrm{mm} /$ tahun). Berdasarkan metode Edijatno-Michel imbuhan airtanah tahunan tertinggi terjadi pada tahun $2016 \quad(237,1$ $\mathrm{mm} /$ tahun) dan terendah terjadi pada tahun 2019 (130,3 mm/tahun).

Tabel 7 merupakan nilai imbuhan airtanah tahunan rata-rata selama lima tahun (2015-2019). Metode Edijatno-Michel memiliki nilai estimasi tertinggi diantara ketiga metode lainnya (186 $\mathrm{mm} /$ tahun), sementara metode Dingman-Hamon memiliki nilai estimasi imbuhan airtanah terendah (125 mm/tahun). Metode Thornthwaite memiliki nilai estimasi imbuhan airtanah sebesar $157 \mathrm{~mm} /$ tahun. Metode Dingman memiliki nilai estimasi nilai Imbuhan sebesar $180 \mathrm{~mm} /$ tahun.

Tabel 7. Nilai imbuhan airtanah berdasarkan empat metode kesetimbangan air.

\section{Imbuhan Airtanah Tahunan (mm/tahun)}

Nilai rata-rata imbuhan airtanah tahunan 2015-2019

\begin{tabular}{lc}
\hline Thornthwaite & 157 \\
Dingman-Hamon & 125 \\
Dingman & 180 \\
Edijatno-Michel & 186 \\
\hline
\end{tabular}

\section{PEMBAHASAN}

Terdapat tiga klaster nilai imbuhan airtanah tahunan dilokasi penelitian yaitu Thronthwaite (157 mm/tahun) Dingman-Hamon (125 $\mathrm{mm} / \mathrm{tahun})$ dan Dingman (180 $\mathrm{mm} / \mathrm{tahun})$ Edijatno-Michel (186 $\mathrm{mm} /$ tahun $)$. Ketiga perbedaan nilai ini disebabkan oleh adanya perbedaan kalkulasi nilai hujan efektif keempat metode tersebut, dimana metode Dingman dan metode Edijatno-Michel memiliki kecenderungan pola kalkulasi yang sama (Lanini,
2015; Lanini dan Caballero, 2016). Kondisi imbuhan airtanah sangat dipengaruhi oleh curah hujan yang ada di lokasi penelitian.

Hujan tahunan rata-rata di lokasi penelitian sekitar 1602,2 $\mathrm{mm} /$ tahun. Jumlah ini cukup berbeda dengan penelitian yang dilakukan oleh (Hartanto, 2017). Perbedaan nilai tersebut disebabkan oleh adanya perbedaan dalam pemilihan lokasi stasiun hujan di lokasi penelitian. Rata-rata nilai evapotranspirasi di lokasi penelitian adalah $1296 \mathrm{~mm} /$ tahun. Nilai ini berbeda dengan penelitian sebelumnya (Hartanto, 2017). Perbedaan nilai disebabkan oleh perbedaan metode estimasi nilai evapotranspirasi. Dimana Hartanto (2017) menggunakan metode Thornthwaite untuk mendapatkan nilai evapotranspirasi potensial. Sedangkan pada penelitian ini menggunakan metode Penman-Montetith (Monteith, 1965). Dengan kondisi seperti diatas, imbuhan airtanah hanya sekitar 7,8-11,6 \% dari jumlah hujan tahunan yang ada di lokasi penelitian. Sekitar $80 \%$ dari hujan tahunan di konversikan menjadi evapotranspirasi potensial dan sisanya menjadi limpasan permukaan. Bulan Agustus merupakan bulan tanpa pengimbuhan airtanah dikarenakan curah hujan pada bulan ini sangat tidak signifikan sehingga lebih banyak terkonversi menjadi nilai evapotranspirasi potensial. Dengan nilai imbuhan airtanah yang kecil, pemanfaatan airtanah di lokasi penelitian memerlukan perhatian khusus. Beberapa bulan bahkan memiliki potensi kekeringan airtanah.

\section{KESIMPULAN}

Metode neraca kesetimbangan air merupakan salah satu metode yang dapat digunakan untuk mengestimasi nilai imbuhan airtanah pada suatu daerah. Studi ini telah sukses mengestimasi nilai imbuhan airtanah berdasarkan metode kesetimbangan air Thornthwaite, Dingman-Hamon dan Edijatno-Michel. Setiap pendekatan memiliki nilai estimasi imbuhan airtanah yang berbeda-beda, namun berada pada rentang dan orde yang sama. Pemilihan neraca kesetimbangan air sebagai metode untuk mengestimasi nilai imbuhan airtanah didasarkan kepada reliabilitas metode ini dalam estimasi imbuhan airtanah serta ketersediaan data curah hujan yang melimpah yang ada di lokasi penelitian. 
Dengan mempertimbangkan kondisi geologihidrometeorologi Indonesia yang cenderung kompleks, estimasi imbuhan airtanah metode Dingman dan metode Edijatno-Michel cenderung optimistik. Hal ini akan berpengaruh kepada overestimasi kalkulasi potensi airtanah yang ada di suatu wilayah. Dengan mempertimbangkan hal di atas, metode Thornthwaite dan metode Dingman-Hamon sangat direkomendasikan untuk perhitungan nilai imbuhan airtanah yang ada di Indonesia. Metode Thornwaite memiliki nilai estimasi yang moderat diantara metode lainnya. Penggunaan estimasi nilai imbuhan airtanah metode Dingman-Hamon sangat disarankan untuk seseorang yang sedang bekerja untuk pemodelan airtanah di suatu wilayah dimana imbuhan airtanah merupakan salah satu input parameter yang dibutuhkan.

Dapat disimpulkan juga bahwa estimasi imbuhan airtanah menggunakan software ESPERE dapat dilakukan secara cepat dan bersamaan dengan sistem multi-method yang bisa disesuaikan dengan ketersediaan data yang dimiliki oleh pengguna. Hal ini merupakan salah satu keunggulan software ESPERE.

\section{UCAPAN TERIMAKASIH}

Dengan telah selesai dan diterbitkannya tulisan ini, penulis mengucapkan terimakasih kepada Dr. Sci. Rachmat Fajar Lubis atas pemilihan topik dan diskusi selama penulisan manuskrip. Terimakasih juga kepada Dr. Edi Irwandi \& Dr. Apip atas diskusi dan saran penyempurnaan tulisan ini. Juga kami ucapkan terimakasih, BMKG Kelas 1 di Serang, BBWS CidanauCiujung-Cidurian Departemen Pekerjaan Umum di Serang.

\section{DAFTAR PUSTAKA}

Agriculture, Ministry of, 2015. Water conservation factsheet: Soil water storage capacity and avilable soil moisture. Water Conservation Factsheet, 1619, 1-4. http://www.droughtmanagement.info/ literature/BC_MA_Soil_Water_Storage_C apacity_2005.pdf.

Anderson, D. M., Glibert, P. M., \& Burkholder, J. M., 2002. Harmful algal blooms and eutrophication: Nutrient sources, composition, and consequences. Estuaries. https://doi.org/10.1007/BF02804901.
Bakundukize, C., van Camp, M., \& Walraevens, K., 2011. Estimation of groundwater recharge in Bugesera Region Burundi using soil moisture budget approach. Geologica Belgica 14(1), 85-102.

Barron, O. V., Barr, A. D., \& Donn, M. J., 2013. Effect of urbanisation on the water balance of a catchment with shallow groundwater. Journal of Hydrology 485, 162-176. https://doi.org/10.1016/j.jhydrol.2012.04.0 27.

Basu, N. B. \& Van Meter, K., 2014. Sustainability of Groundwater Resources. Comprehensive Water Quality and Purification 4, 57-75. https://doi.org/ 10.1016/B978-0-12-382182-9.00062-1.

Böhlke, J. K., 2002. Groundwater recharge and agricultural contamination. Hydrogeology Journal 10 (1), 153-179. https://doi.org/ 10.1007/s10040-001-0183-3.

Boughton, W., 2005. Catchment water balance modelling in Australia 1960-2004. Agricultural Water Management 71(2), 91116. https://doi.org/10.1016/j.agwat. 2004.10.012.

Chapman, T.G. \& Maxwell, A.I., 1996. Baseflow separation-Comparison of numerical methods with tracer experiments. Proceedings of Hydrology and Water Resources Symposium 1996, Publication 96/05, 539-545. Barton, Australia: Institution of Engineers Australia, Hobart.

D’Almeida, C., Vörösmarty, C. J., Marengo, J. A., Hurtt, G. C., Dingman, S. L., \& Keim, B. D., 2006. A water balance model to study the hydrological response to different scenarios of deforestation in Amazonia. Journal of Hydrology 331 (1-3), 125-136. https://doi.org/10.1016/j.jhydrol.2006.05.0 27.

de Vries, J. J. \& Simmers, I., 2002. Groundwater recharge: An overview of process and challenges. Hydrogeology Journal 10, 5-17. https://doi.org/10.1007/s10040-001-0171-7

Delin, G.N., Healy, R.W., Lorenz, D.L., \& Nimmo, J.R., 2007. Comparison of localto regional-scale estimates of groundwater recharge in Minnesota, USA. Journal of Hydrology 334 (1-2), 231-249. 
Dingman, S. L., 2015. Physical Hydrology, 3rd ed. Waveland Press. Long Grove, Illinois. $643 \mathrm{pp}$.

Dingman, S. L., 2002. Physical Hydrology, 2nd ed. Waveland Press. Long Grove, Illinois. 575 pp.

Eckhardt, K., 2005. How to construct recursive digital filters for baseflow separation. Hydrological Processes 19 (2), 507-515.

Edijatno dan Michel C., 1989. Un modèle pluiedébit journalier à trois paramètres. La Houille Blanche, $\mathrm{n}^{\circ} 2$, pp 113-122. https://doi.org/10.1051/1hb/1989007.

FAO, 2018. CROPWAT 8.0. In Land and water, databases and software, CropWat.

Gleeson, T., Wada, Y., Bierkens, M. F. P., \& Van Beek, L. P. H., 2012. Water balance of global aquifers revealed by groundwater footprint. Nature 488, 197-200. https://doi.org/10.1038/nature11295.

Guardiola-Albert, C., Martos-Rosillo, S., PardoIgúzquiza, E., Durán Valsero, J. J., Pedrera, A., Jiménez-Gavilán, P., \& Liñán Baena, C., 2015. Comparison of Recharge Estimation Methods During a Wet Period in a Karst Aquifer. Groundwater 53(6), 885-895. https://doi.org/10.1111/ gwat. 12310

Guttman, J., \& Zuckerman, H., 1995. Flow model in the eastern basin of the Judea and Samaria hills. Report No. 01/95/ 66. In Hebrew. Tel Aviv, Israel: Tahal Consulting Engineers Ltd.

Hamon, W.R., 1961, Estimating potential evapotranspiration: Journal of the Hydraulics Division, Proceedings of the American Society of Civil Engineers 87, 107-120.

Hartanto, P., 2017. Perhitungan neraca air DAS Cidanau menggunakan metode Thornthwaite. RISET Geologi Dan Pertambangan, 27(2), 213-225. https://doi.org/10.14203/risetgeotam2017.v 27.443 .

Hartanto, P., Delinom, R. M., \& Hendarmawan, H., 2019. Kualitas air pada puncak musim kemarau di Daerah Rawa Danau Kabupaten Serang. RISET Geologi Dan
Pertambangan, 29(1), 13-25. https://doi. org/10.14203/risetgeotam2019.v29.1021.

Hidayah, E., Iriawan, N., Anwar, N., \& Edijatno, E., 2011. Generating Hourly Rainfall Model using Bayesian Time Series Model A Case Study at Sentral Station, Bondowoso. IPTEK The Journal for Technology and Science 22(1), 50-56. https://doi.org/10.12962/j20882033.v22i1.5 7 .

Islam, S., Singh, R. K., \& Khan, R. A., 2016. Methods of estimating groundwater recharge. International Journal of Engineering Associates 5(2), 6-9.

Jaworska-Szulc, B., 2009. Groundwater flow modelling of multi-aquifer systems for regional resources evaluation: The Gdansk hydrogeological system, Poland. Hydrogeology Journal 176, 1521-1542. https://doi.org/10.1007/s10040-009-0473-8

Johnson, A. I., 1967. Specific Yield Compilation of Specific Yields for Various Materials-Hydrologic properties of earth materials. Geological Survey Water-Supply Paper 1662-D, 80. https://pubs.usgs.gov/wsp/ $1662 \mathrm{~d} /$ report.pdf

Kessler, H., 1967, Water balance investigations in the karstic regions of Hungary. Red Book IASH n73., Dubrovnik Symposium, Oct., 1965, 91-105, http://ks360352. kimsufi.com/redbooks/073.html.

Kobiyama, M., 2008. Water balance in CubatãoSul river catchment, Santa Catarina, Brazil. Ambiente e Agua - An Interdisciplinary Journal of Applied Science 3(1), 5-17. https://doi.org/10.4136/ambi-agua.38.

Konikow, L.F., \& Kendy, E., 2005. Groundwater depletion: A global problem. Hydrogeology Journal 13, 317-320. https://doi.org/10.1007/s10040-004-0411-8

Křeček, J., Turek, J., Ljungren, E., Stuchlík, E., \& Šporka, F., 2006. Hydrological processes in small catchments of mountain headwater lakes: The Tatra Mountains. Biologia 61(18), S1-S10. https://doi.org/ 10.2478/ s1 1756-006-0115-8.

Lanini, S., 2015. ESPERE User Guide. 
Lanini, S., \& Caballero, Y., 2016. Groundwater recharge and associated uncertainty estimation combining multi-method and multi-scale approaches. Environmental Modelling and Software for Supporting a Sustainable Future, Proceedings - 8th International Congress on Environmental Modelling and Software, IEMSs 2016, $553-560$

Lanini, Sandra, Caballero, Y., Seguin, J.J., \& Maréchal, J.C., 2016. ESPERE-A MultipleMethod Microsoft Excel Application for Estimating Aquifer Recharge. Groundwater 54(2), 155-156. https://doi.org/10.1111/ gwat. 12390

Mauser, W. \& Ludwig, R., 2016. Groundwater recharge. In: Mauser W., Prasch M. (eds) Regional Assessment of Global Change Impacts. Springer, Cham. https://doi.org/ 10.1007/978-3-319-16751-0 24.

Mintz, Y. \& Serafini, Y.V., 1992. A global monthly climatology of soil moisture and water balance. Climate Dynamics 8, 13-27. https://doi.org/10.1007/BF00209340.

Monteith, J.L., 1965. Evaporation and environment. Symposia of the Society for Experimental Biology 19, 205-235.

Niazi, A., Bentley, L.R., \& Hayashi, M., 2017. Estimation of spatial distribution of groundwater recharge from stream baseflow and groundwater chloride. Journal of Hydrology 546, 380-392. https://doi.org/10.1016/j.jhydrol.2017.01.0 32.

Rogers, B.P. \& Hall, A.W., 2003. Effective Water Governance. Global Water Partnership. Stockholm. 45 pp.

Rusmana, E., Suwitodirdjo, K., \& Suharsono, 1991. Peta Geologi Lembar Serang Jawa Skala 1:100.000, Pusat Survey Geologi, Bandung.

Sanford, W., 2002. Recharge and groundwater models: An overview. Hydrogeology Journal 10, 110-120. https://doi.org/ 10.1007/s10040-001-0173-5

Santosa, S., 1991. Peta Geologi Lembar Anyer Jawa Barat, Skala 1:100.000, Pusat Survey Geologi, Bandung.
Seiler, K. -P. \& Gat, J.R., 2007. Groundwater recharge from runoff, infiltration and percolation. Springer. Netherlands. $248 \mathrm{pp}$. https://doi.org/ 10.1007/978-1-4020-5306-1

Simmers, E.I., 1987. Estimation of natural groundwater recharge. EOS 70(9), 131. https://doi.org/10.1029/89eo00076.

Singh, A., Panda, S.N., Uzokwe, V.N E., \& Krause, P., 2019. An assessment of groundwater recharge estimation techniques for sustainable resource management. Groundwater for Sustainable Development 9, 100218. https://doi.org/ 10.1016/j.gsd.2019.100218

Thornthwaite, C.W., 1948. An approach toward a rational classification of climate. Geographical Review 38, 55-94.

Tilahun, K. \& Merkel, B.J., 2009. Estimation of groundwater recharge using a GIS-based distributed water balance model in Dire Dawa, Ethiopia. Hydrogeology Journal 17, 1443-1457. https://doi.org/10.1007/ s10040-009-0455-x.

Turc, L., 1954, Le bilan d'eau des sols: Relations entre les précipitations, l'évaporation et l'écoulement., Annales Agronomiques, 5, 491-595.

Van Der Kaars, S., Penny, D., Tibby, J., Fluin, J., Dam, R.A.C., \& Suparan, P., 2001. Late Quaternary palaeoecology, palynology and palaeolimnology of a tropical lowland swamp: Rawa Danau, West-Java, Indonesia. Palaeogeography, Palaeoclimatology, Palaeoecology 171 (3-4), 185212 . https://doi.org/10.1016/S00310182(01)00245-0.

Vörösmarty, C.J., Green, P., Salisbury, J., \& Lammers, R.B., 2000. Global water resources: Vulnerability from climate change and population growth. Science 289 (5477), 284-288. https://doi.org/10.1126/ science. 289.5477 .284 .

Wagner, P.D., Kumar, S., \& Schneider, K., 2013. An assessment of land use change impacts on the water resources of the Mula and Mutha Rivers catchment upstream of Pune, India. Hydrology and Earth System Sciences 17, 2233-2246. https://doi.org/ 10.5194/hess-17-2233-2013. 
Wahyuningsih, S., Anwar, N., Edijatno, E., \& Karnaningroem, N., 2010. A Comparative Study of Water Quality Characteristics at East Java River. IPTEK The Journal for Technology and Science 21(4). https://doi.org/10.12962/j20882033.v21i4.9 1.

Westenbroek, M.S., Kelson, V.A., Dripps, W.R., Hunt, R.J., \& Bradbury, K.R., 2010. SWB - A Modified Thornthwaite-Mather SoilWater- Balance Code for Estimating Groundwater Recharge. U.S. Geological Survey Techniques and Methods 6-A31, $60 \mathrm{pp}$.

Xu, C.Y. \& Chen, D., 2005. Comparison of seven models for estimation of evapotranspiration and groundwater recharge using lysimeter measurement data in Germany. Hydrological Processes 19(18), 3717 3734. https://doi.org/10.1002/hyp.5853.
Yeh, H.F., Lee, C.H., Chen, J.F., \& Chen, W.P., 2007. Estimation of groundwater recharge using water balance model. Water Resources 34, 153 - 162. https://doi.org/ 10.1134/S009780780702005

Zhang, L., Dawes, W. R., \& Walker, G. R., 1999. Predicting the Effect of Vegetation Changes on Catchment Average Water Balance. Technical Report. Cooperative Research Centre for Catchment Hydrology. https://ewater.org.au/archive/crcch/archive/ pubs/pdfs/technical199912.pdf. 